\title{
Is Isostatic Rebound in Slow Spreading Gakkel Ridge of Arctic Region Due to the Climate Change? A Case Study
}

\author{
Arun Kumar, L. Sunil Singh \\ Department of Earth Sciences, Manipur University, Imphal, India \\ Email: arun634@gmail.com
}

Received December 31, 2011; revised February 22, 2012; accepted March 23, 2012

\begin{abstract}
Ny-Alesund, Swalbard region which is located in the mid-ocean ridge of the Arctic Ocean, and named Gakkel ridge, is the slowest spreading ridge of the global system. In the present study an attempt has been made to associate isostatic rebound using GPS campaign data collected at Ny-Alesund area. The Artic Region Campaign GPS network was established in 2009. The network consists of three campaign mode station. The distance between GPS point is about $\sim 30 \mathrm{~km}$. The preliminary results of our investigation appear broadly consistent with the recent tectonic activity in western Svalbard. The resultant velocity vector is $14.84 \mathrm{~mm} \cdot \mathrm{yr}^{-1}$ with an azimuth of $27.67^{\circ} \mathrm{N}$ and a vertical displacement of $7.62 \pm$ $3.0 \mathrm{~mm} \cdot \mathrm{yr}^{-1}$ is estimated in Swalbard, in which we presume Glacial Isostatic Rebound $\left(5.1 \mathrm{~mm} \cdot \mathrm{yr}^{-1}\right)$ and post glacial geological process (Present Day Ice Melting, erosion, and shore line deposits) of $2.52 \mathrm{~mm}$ per year in the study area.
\end{abstract}

Keywords: Isostatic Rebound; Artic Region; GPS Processing; Crustal Deformation

\section{Introduction}

Much of Northern Europe, Asia, North America, Greenland and Antarctica were covered by ice sheets during the last glacial period. The ice was as thick as three kilometres about 20,000 years ago. The enormous weight of this ice results in the deformation of the Earth's crust and warp downward, forcing the visco-elastic mantle material to flow away from the loaded region. At the end of each glacial period when the glaciers retreated, the removal of the weight from the depressed land led to slow (and still ongoing) uplift or rebound of the land and the return flow of the mantle material back under the deglaciated area. Due to the large viscosity $\left(3 \times 10^{21} \mathrm{P}\right)$ [1] of the mantle, it will take thousands of years for the land to reach an equilibrium level.

Several studies have shown that the uplift has taken place in two distinct stages. The initial was near-instantaneous due to the elastic response as the ice load was removed. After this elastic phase, uplift was slow due to viscous flow and the rate of uplift decreased exponentially. Today, typical uplift rates are of the order of 1 $\mathrm{cm} \cdot \mathrm{yr}^{-1}$ or less. In northern Europe, this is clearly shown by the GPS data obtained by the BIFROST GPS network [2]. Studies suggest that rebound will continue for at least another 10,000 years. The total uplift from the end of deglaciation depends on the local ice load and could be several hundred metres near the centre of rebound.

Recently, the term Post-Glacial Rebound is gradually being replaced by the term glacial isostatic adjustment. This is in recognition that the response of the Earth to glacial loading and unloading is not limited to the upward rebound movement, but also involves downward land movement, horizontal crustal motion [2,3], changes in global sea levels [4], the Earth's gravity field, [5], induced earthquakes [6] and changes in the rotational motion [7].

\section{Gakkel Ridge}

The Gakkel Ridge (formerly known as the Nansen Cordillera and Arctic Mid-Ocean Ridge) is a mid-oceanic ridge, a divergent tectonic plate boundary between the North American Plate and the Eurasian Plate. It is located in the Arctic Ocean between Greenland and Siberia (Figure 1) with a length of about 1800 kilometers. Geologically, it connects the northern end of the Mid Atlantic Ridge with the Laptev Sea Rift. Gakkel ridge is the slowest spreading ridge of the global system of mid-oceanic ridges with full spreading rates declining from about 12.5 to $6 \mathrm{~mm} \cdot \mathrm{yr}^{-1}$ from west to east [8]. The existence and approximate location of the Gakkel Ridge was predicted by a Soviet polar explorer Yakov Yakovlevich Gakkel and discovered by Soviet Arctic Expeditions in the late forties - early fifties of the 20th century. The Ridge is named after him.

Seismotectonically, the Gakkel is active as evidenced by the presence of earthquakes of magnitude $>3.5$ at 


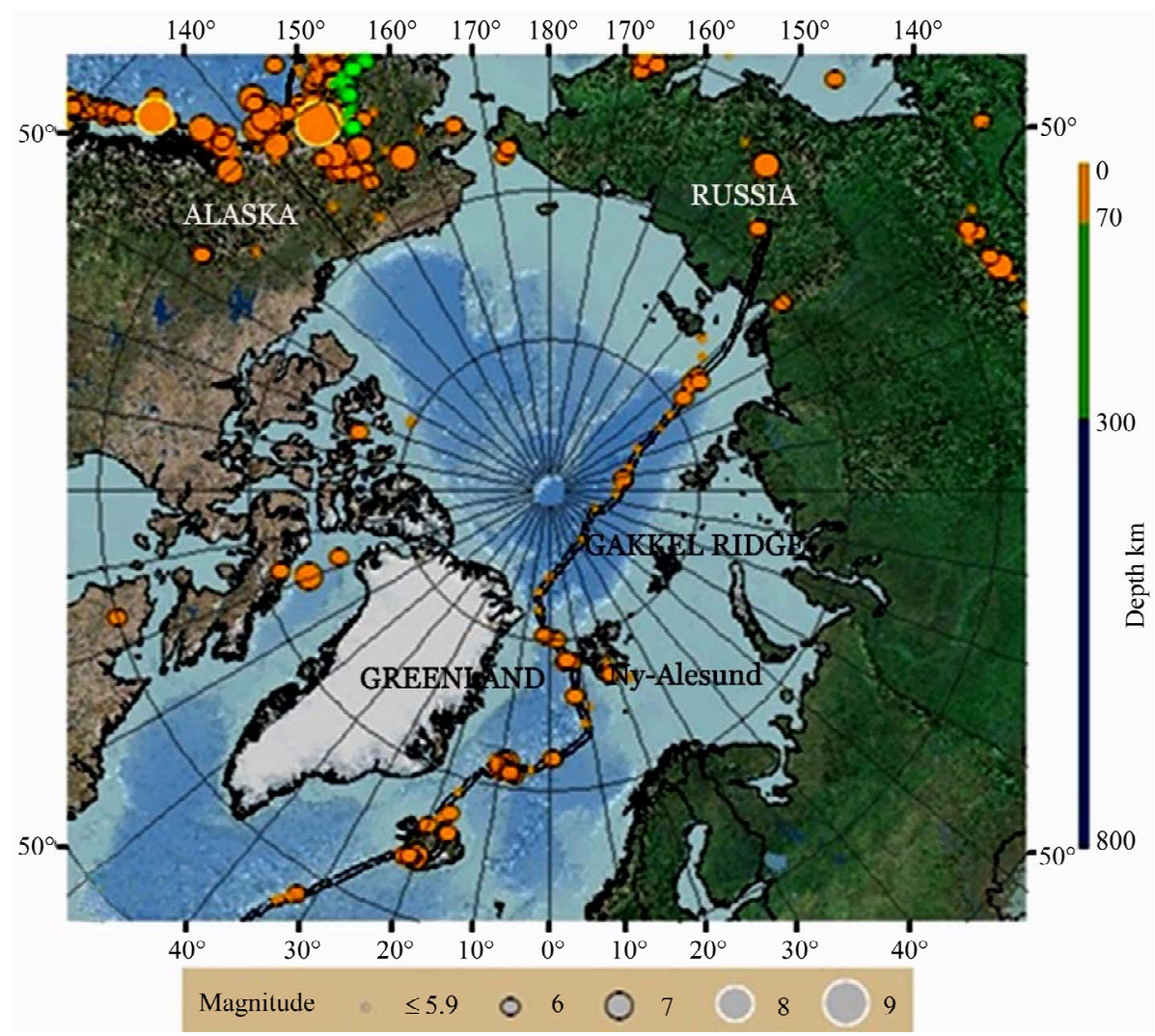

Figure 1. The Gakkel Ridge.

shallower depths than $30 \mathrm{~km}$. They caused the slope failure in regions of unstable methane hydrate and further cause giant plumes of methane to be released and enter the atmosphere. Earthquakes have been increasing in frequency and magnitude along the Gakkel Ridge and peaked in frequency in 1999 when there were 252 measurable earthquakes with magnitudes as high as 4 to 6 . These earthquakes were initially focused at the crust-mantle boundary, 16 to $20 \mathrm{~km}$.

The earthquake activity was apparently associated with magma ascension along the down but then rose up to the magma conduit ridge and the subsequent submarine explosive volcanic eruptions. Fault activation due to the magmatic emplacement covered a very wide region [8]. The peak yearly frequency of magnitude 4 to 6 earthquakes on the Gakkel Ridge is mirrored by a major peak in worldwide Great and Major Earthquakes (>Magnitude 7) and a peak in the atmospheric methane. Therefore Gakkel Ridge magma emplacement earthquakes, Arctic subsea explosive volcanicity and fault activation over a wide area is clearly directly linked to the destabilization of the submarine slope Arctic methane hydrates and release of abundant methane to the Arctic atmosphere.

\section{Geology \& Tectonics}

Svalbard is located in the north western corner of the
Barents Shelf (Figures 2 and 3). The archipelago represents an uplifted part of this otherwise submerged shelf. The uplift was most extensive in the north and west, leaving progressively older rocks in these directions.

A pronounced synclinal feature, the Central Spitsbergen Basin, occupies most of central Spitsbergen. The basin is bounded to the west by the West Spitsbergen fold-andthrust belt, which die out towards the eastern part of Spitsbergen. The basin boundaries parallel a dominant NNW-SSE structural grain on Spitsbergen comprised through four similarly aligned episodes of tectonic deformation.

Ny-Alesund is located in NW Spitsbergen of Svalbard archipelago in the Arctic Ocean. It provides varied geological structures and geo-historical development since the palaeo-Proterozoic time and is well known for having rocks of all the geological ages with multi orogenic development and prominent tectonic events $[10,11]$.

The last recognised important tectonic event in this area is dated from the late Tertiary, [12], when sediments of the Ny Ålesund tertiary basin have been overthrusted by older, carboniferous rocks. From this late Tertiary event onwards, the area of Ny Ålesund (western Svalbard) is supposed to have mainly been affected by post-glacial rebound processes.

Plag H. B. [13] of Norwegian Mapping Authority sug- 
gested that Western part of Svalbard, despite its nearness to the Mid-Atlantic ridge, is on the stable part of the European Plate. Tomasai and Rioja [14] further supported the idea evident by small base line changes between Ny-Alesund and Wettzell. However, in more recent times, high heat flow anomalies and a sparse seismic activity have been recorded from offshore western Svalbard [15], suggesting that this province and its adjacent onshore continuation could still be tectonically active domains. Bockmann [16] reported indicate neo-tectonic movements and a possible small scale tectonic movement from the results of GPS campaign data in the region.

This region is usually considered to be stable from the plate tectonics standpoint. But if this is true for continental Scandinavia the situation of Svalbard is quite different. The western Svalbard fold-and-thrust belt has a complex tectonic history linked to the opening of the Northern Atlantic Ocean. This area is located close to the Hornsund Fault Zone, one of the major active fault zones during the separation of the NE Greenland and SvalbardBarents shelves. The last recognised important tectonic event in this area is dated from the Tertiary [12], when the Ny Ålesund Tertiary basin has been overthrusted by carboniferous rocks (Figures 2 and 3). But western Svalbard is located only $150 \mathrm{~km}$ far from the Knipovich Ridge, which is considered an active segment of the MidAtlantic Ridge system. High heat flow anomalies and considerable seismic activity (Figure 4) have been recorded from offshore western Svalbard [15] showing that the area is tectonically active and in the Kings Bay area, minor seismicity may indicate some neo-tectonic activity.
During Pleistocene time this area was covered by a thick ice sheet. The entire region is now affected by a post-glacial rebound as result of isostatic response to the melting of the ice shield about 10,000 years ago. This phenomenon induces an obvious vertical motion but also a tangential deformation with horizontal displacement at the transition between the central dome and the forebulge area. (Geological data based on raised shore deposit give $3.3 \mathrm{~mm} \cdot \mathrm{yr}^{-1}$ uplift at Kvadehuksletta west of Ny Ålesund [11] during the last $9 \mathrm{kyr}$, and $2.8 \mathrm{~mm} \cdot \mathrm{yr}^{-1}$ uplift at Recherche Fjord [17,18]. Furthermore massive erosion of the Svalbard linked to glacial and post-glacial geomorphological processes, leads to mass redistribution and may increase the post-glacial effects (raised shore lines). [11,19,20]: $\sim 330 \mathrm{~km}^{3}$ sedimentary wedge offshore Isfjorden between $200 \mathrm{ka}$ and $13 \mathrm{ka}$ (rate: $\sim 7.9 \times 106$ $\left.\mathrm{m}^{3} \cdot \mathrm{a}^{-1}\right)$.

Gakkel spreading Ridge is seems to be slow spreading ridge and the Svalbard areas are located south of the ridge, which shows the evidences of mainly local deformations along faults and part of it can be accommodated in the isostatic rebound due to climate change activities. The aim of this study is to carry out a preliminary deformation analysis using the GPS campaign data from years 2009-2011 to resolve local deformation expected in the course of the glacial induced isostatic rebound (Figure 5).

\section{Network and GPS Measurements}

In order to carry out the crustal deformation studies of Artic Region a geodetic network comprising of three

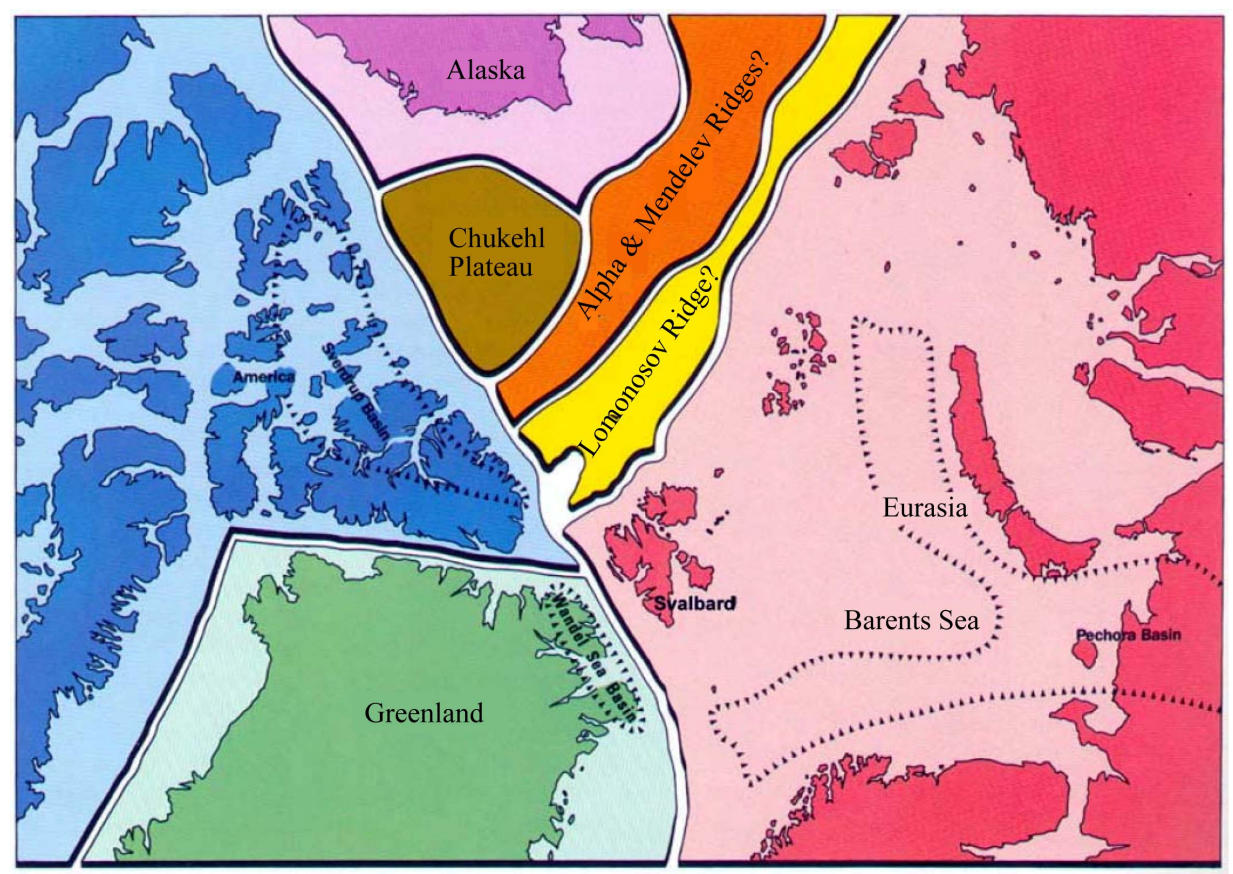

Figure 2. Plate configuration in the Arctic prior to opening of the Atlantic and the Polar Basin [9]. 


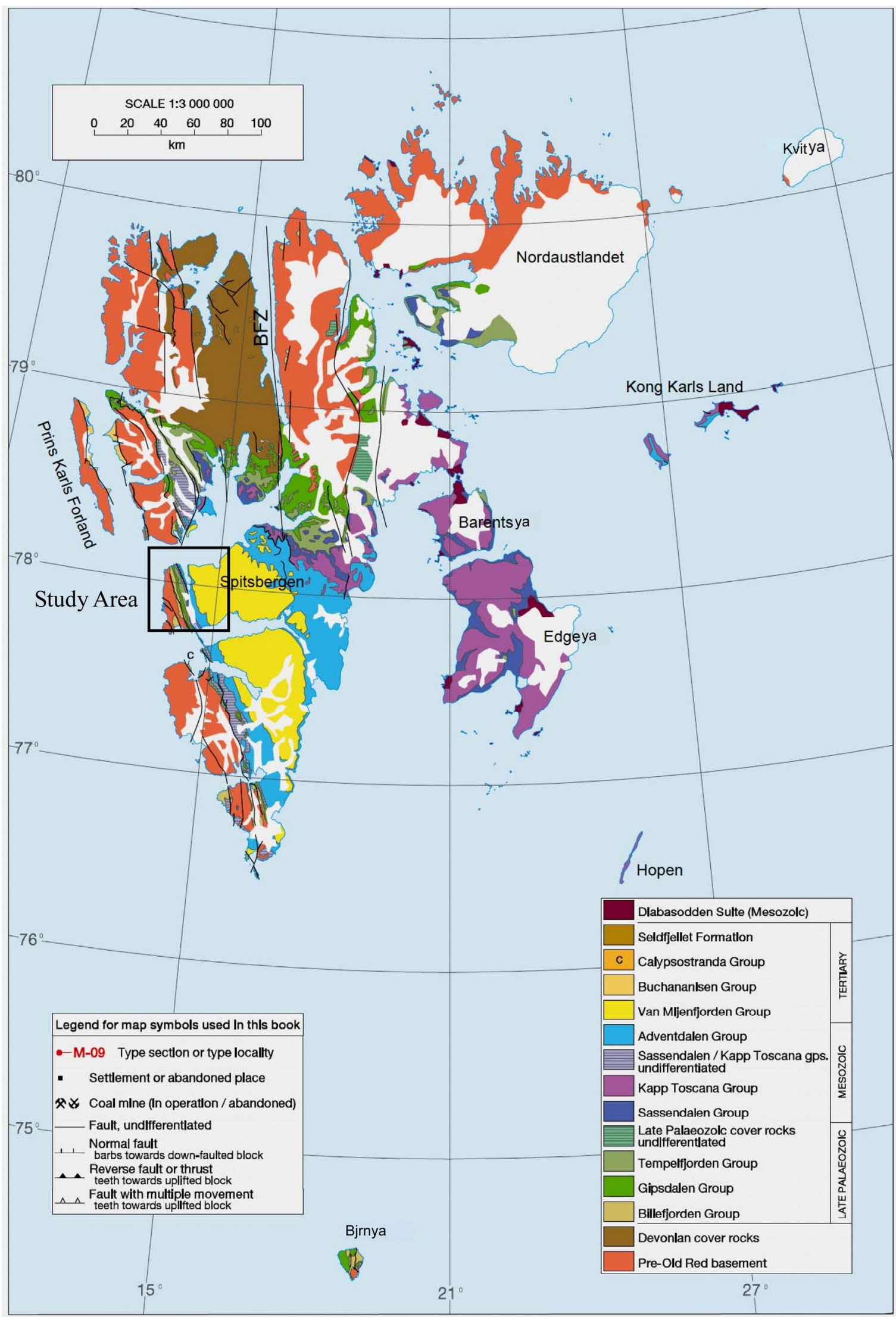

Figure 3. Simplified geological map of Svalbard [21]. 


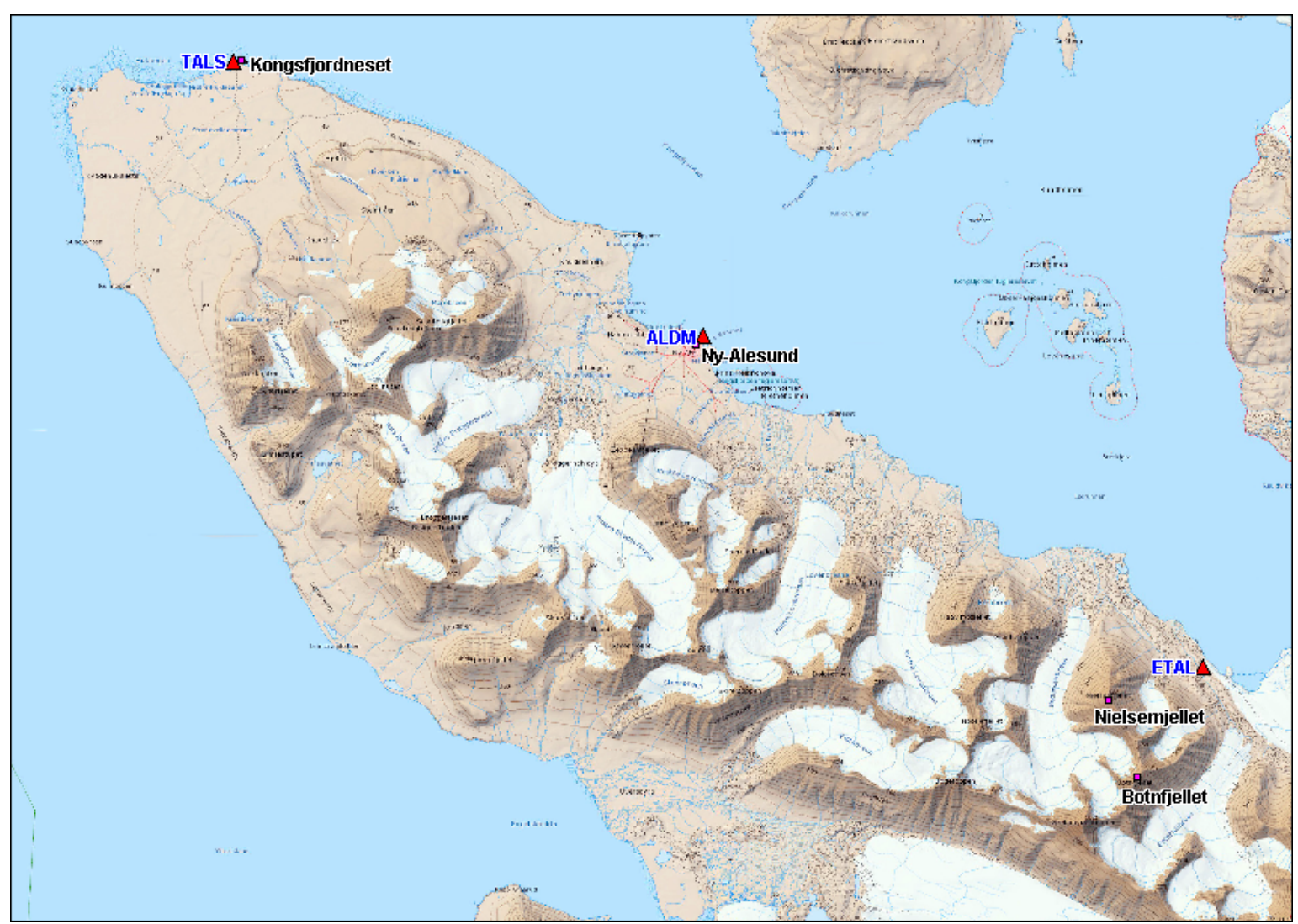

Figure 4. Location map of GPS campaign site at Arctic Region.

stations (Figure 4 and Table 1) has been established. The first GPS campaign measurements were initiated during August 2009 with the establishment of three sites, Ny-Alesund (ALDM), Western tip of Ny-Alesund (ETAL) and Eastern tip of Ny-Alesund (TALS) of Artic. These GPS campaign stations are equipped with Leica GX1200 GPS receivers with choke ring and Zephyr geodetic antennae. All the sites selected are in the open area on the ground. The distance between two GPS point is about 30 $\mathrm{km}$.

\section{Monumentation}

The Monumentation normally set eventually will become unnecessary when active control networks have been established. Things to consider when establishing monumentation include precision and environment. If high precision $(<1 \mathrm{~cm})$, repeatable results are desired, the mark itself should be $1 \mathrm{~mm}$ in diameter and the marker should be durable and stable in its medium. All markers should be resistant to weathering, but the type of marker used may be dictated by land use.

Campaign geodetic monuments for each campaign site were set up using small drilling machine. The hole about $1 / 2$ " deeper than the pin, the preferred method is to achieve a friction fit between the pin and the rock. The hole tends to widen near the top, because the bit pivots about its tip early in the drilling. Drill the hole, and blow all dust out of the hole with a long flexible tube. And check how far the pin will fall into the hole. Stainless brass pin about 3/4-inch pin were anchored into the holes using epoxy.

Data at these sites were recorded with conventional 30 -second samples continuously for more than three day.

\section{GPS Processing}

The GPS data obtained from the campaign site has been converted into RINEX observation files and quality check has been performed using TEQC (Translation, Editing and Quality Checking Software). The quality check plots of all the GPS data were carefully examined and the data with high cycle clips were carefully examined and the data with high cycle clips multipath and $<12 \mathrm{~h}$ observation were removed from the analysis.

The GPS data were processed using the GAMIT/ GLOBK [22,23] software package. In addition to the GPS data collected from study area, we processed data from a number of International Global Navigational Statelite System Service (IGS) permanently operating stations (Figure 6) in and around the region (dav1, hofn, kir0, mawl, nril, nyal, nyal, reyk, scor, trol,vesl). We com- 
Table 1. GPS campaign stations (WGS84: Geodetic-unprojected).

\begin{tabular}{cccccc}
\hline Sl. No & Name & Identifier & Latitude & Longitude & Height (m) \\
\hline 1 & Ny Ålesund & ALDM & $78^{\circ} 55^{\prime} 38.11^{\prime \prime}$ & $11^{\circ} 56^{\prime} 14.14^{\prime \prime}$ & 33.46 \\
2 & Western tip of Ny Ålesund & ETAL & $78^{\circ} 52^{\prime} 17.66^{\prime \prime}$ & $12^{\circ} 25^{\prime} 48.48^{\prime \prime}$ & 65.98 \\
3 & Eastern tip of Ny Ålesund & TALS & $78^{\circ} 58^{\prime} 23.49^{\prime \prime}$ & $11^{\circ} 28^{\prime} 28.38^{\prime \prime}$ & 42.42 \\
\hline
\end{tabular}

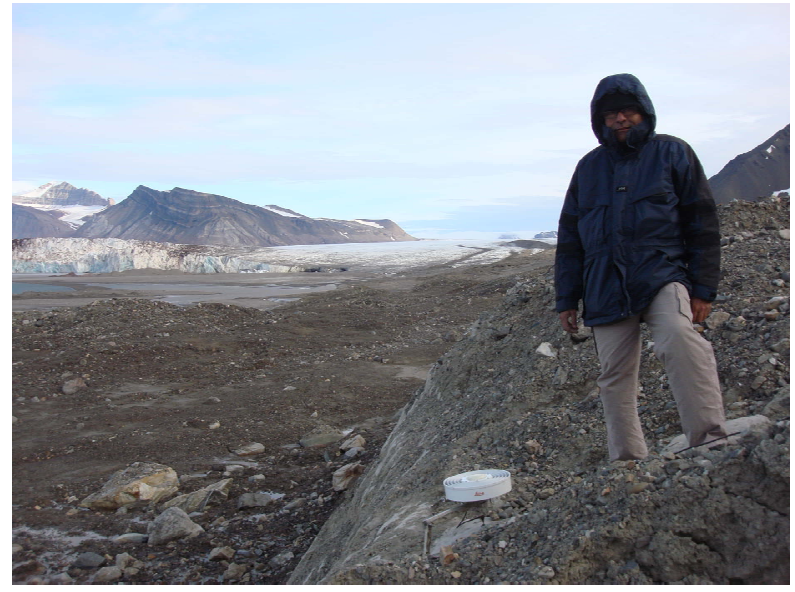

Figure 5. GPS monument at ALDM.

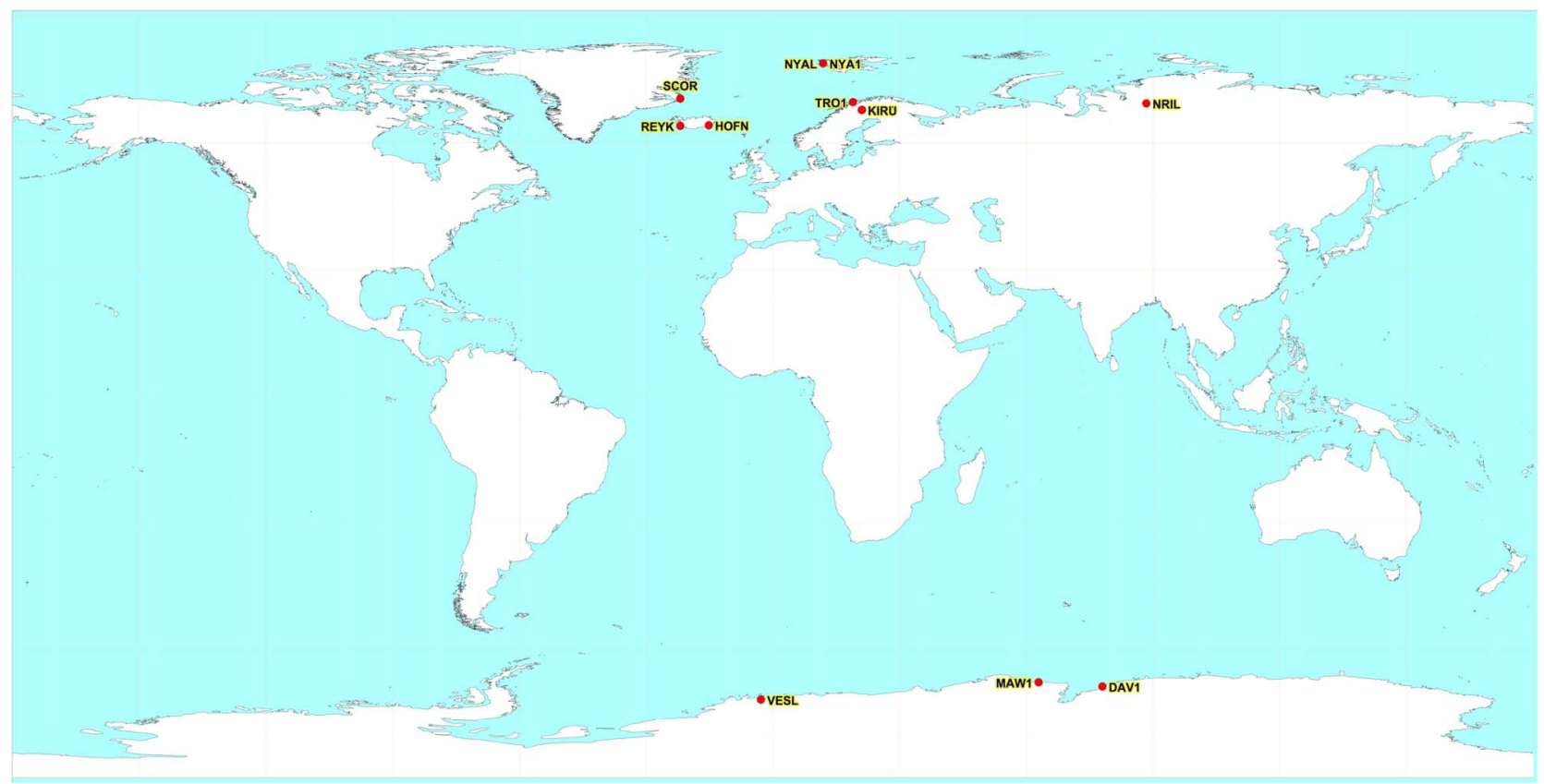

Figure 6. IGS stations used in the processing.

bined our own solution with daily solutions of global IGS stations processed and archived at the Scripps Orbital and Permanent Array Centre (SOPAC). The International Terrestrial Reference Frame (ITRF) 2005 [24], was defined by applying translation and rotation parameters that minimize the horizontal velocities of sites assumed to lie within the stable plate interior.

\section{Results}

Figures 7 and 8 shows the computed GPS velocities and the series plot of the campaign sites respectively. The resultant vector of TALS is more than ALDM and ETAL. The maximum and minimum root mean square (RMS) errors are $0.003 \mathrm{~m}$ and $0.001 \mathrm{~m}$ respectively. The small values of $R M S$ indicate the results obtained are precise 


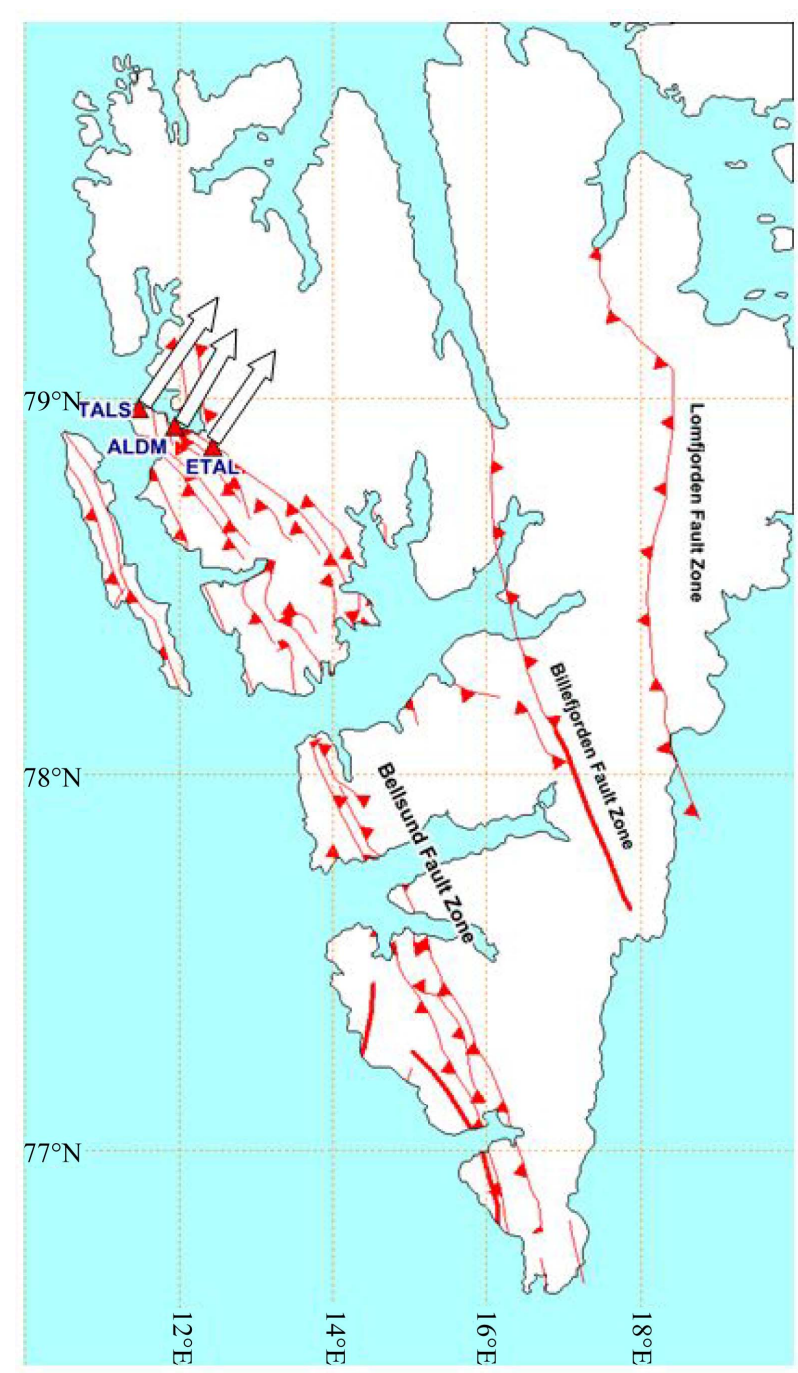

Figure 7. Estimated velocity plot along with the major tectonic features in and around Ny Ålesund area.

and reliable. It is readily seen that the RMS statistic is very well behaved and that there is no tension as each day of observation is added to the next. In particular there is no tension for the campaign data between the 2009, 2010 and 2011. This means that the detected movement at stations, ALDM, TALS an ETAL was well determined. However with only three surveys performed so far there is insufficient evidence.

\section{Discussion}

We also compared our results with secular displacement and gravity rates observed in the Swalbard region where the Predicted Present Day Ice Melting rate of 2.04 $\mathrm{mm} \cdot \mathrm{yr}^{-1}$ for the nominal melting rate of $-47 \mathrm{~cm} \cdot \mathrm{yr}^{-1}$ gives a uplift rate of $5.1 \mathrm{~mm} \cdot \mathrm{yr}^{-1}$ that is consistent with the observed rate of $5.2 \pm 0.6 \mathrm{~mm} \cdot \mathrm{yr}^{-1}$ [25]. It can be concluded from the above discussion that there are local deformations along existing faults, which seems to be ac- tive. The resultant vector of Ny-Alesund (ALDM) is 14.84 $\mathrm{mm} \cdot \mathrm{yr}^{-1}$ with an azimuth $27.67^{\circ} \mathrm{N}$ with a vertical displacement of $7.62 \pm 3.0 \mathrm{~mm} \cdot \mathrm{yr}^{-1}$, which is not due to only the isostatic rebound. It is necessary to consider the effects of upper mantle viscosity, which may give some errors in the estimates of the vertical uplift due to the post glacial isostatic rebound. There was an attempt [24] in 2006 to estmate the viscosity at study area and gravity rates. The gravity rates are $-2.5 \mu \cdot \mathrm{Gal}^{\circ} \cdot \mathrm{yr}^{-1}$ and the corrected rates of sea level rise correspond $20 \%-30 \%$ error. For the verti- cal component, the ice model effect [24] give a similar rates $1.2-1.9 \mathrm{~mm} \cdot \mathrm{yr}^{-1}$ and $-0.3 \mu \cdot \mathrm{Gal}^{\cdot} \mathrm{yr}^{-1}$ with nominal upper mantle viscosity value assumed for their study. We have compared our rates of uplift with the earlier studies [24], in which $5.2 \mathrm{~mm} \cdot \mathrm{yr}^{-1}$ and gravity rates $-2.5 \mu \cdot \mathrm{Gal} \cdot \mathrm{yr}^{-1}$ and viscosity rates for vertical component are $3 \mathrm{~mm} \cdot \mathrm{yr}^{-1}$ and $-1.9 \mu \cdot \mathrm{Gal}^{\cdot} \mathrm{yr}^{-1}$. We considered the possi- bilities of other discrepancies due to various geological processes such as raised shore line deposits and high ero- sion rates (Figure 9) at Ny Alesund [26-29]. There is possibility that massive erosion at Svalbard led to mass redistribution that may enhance the post glacial rebound effect. After the consideration of the effect of geological processes, their rates are estimated [24] as $3.1 \mathrm{~mm} \cdot \mathrm{yr}^{-1}$. The predicted post glacial normal ice melting of the $2.04 \mathrm{~mm} \cdot \mathrm{yr}^{-1}$ for normal melting of $-47 \mathrm{~mm} \cdot \mathrm{yr}^{-1}$ gives an uplift rates of $5.2 \mathrm{~mm} \cdot \mathrm{yr}^{-1}$.

The vertical uplift rates (PGR) are also measured in Green land in Sisimint and Disco Bay $\left(1.6 \mathrm{~mm} \cdot \mathrm{yr}^{-1}\right)$, which is located east of the Gakkel Ridge [30]. The region is affected by the retreat of ice margin during the last $150 \mathrm{yr}$. The present day sea level rise is $4 \mathrm{~mm} \cdot \mathrm{yr}^{-1}$ in the outermost part of the Greenland.

The most recent results obtained by different geodetic techniques (VLBI, GPS) show a motion of the Ny Ålesund station up to $6 \mathrm{~mm} / \mathrm{yr}$. in vertical component, that cannot be explained by post-glacial rebound only. The investigation on the stability of the site combining both structural geological and classical geodetic techniques is made at NyAlesund [31]. For this purpose, an integrated geodetic network (spirit levelling and GPS) was established and measured in July 2002, in order to verify the stability of VLBI antenna site. The Preliminary results of our investigation appear broadly consistent with the hypothesis of active, or at least very recent tectonic activity in western Svalbard.

Based on the various comparisions from the earlier studies, our results of uplifting of the NyAlesund is due to the post glacial isostatic rebound as well as various geological processes also contribute to the high ice melting. If confirmed by further work, this finding may yield relevant constraints to an enhanced understanding of the recent tectonic evolution of the arctic region. We may infer that these GPS data reveal the process of climate 


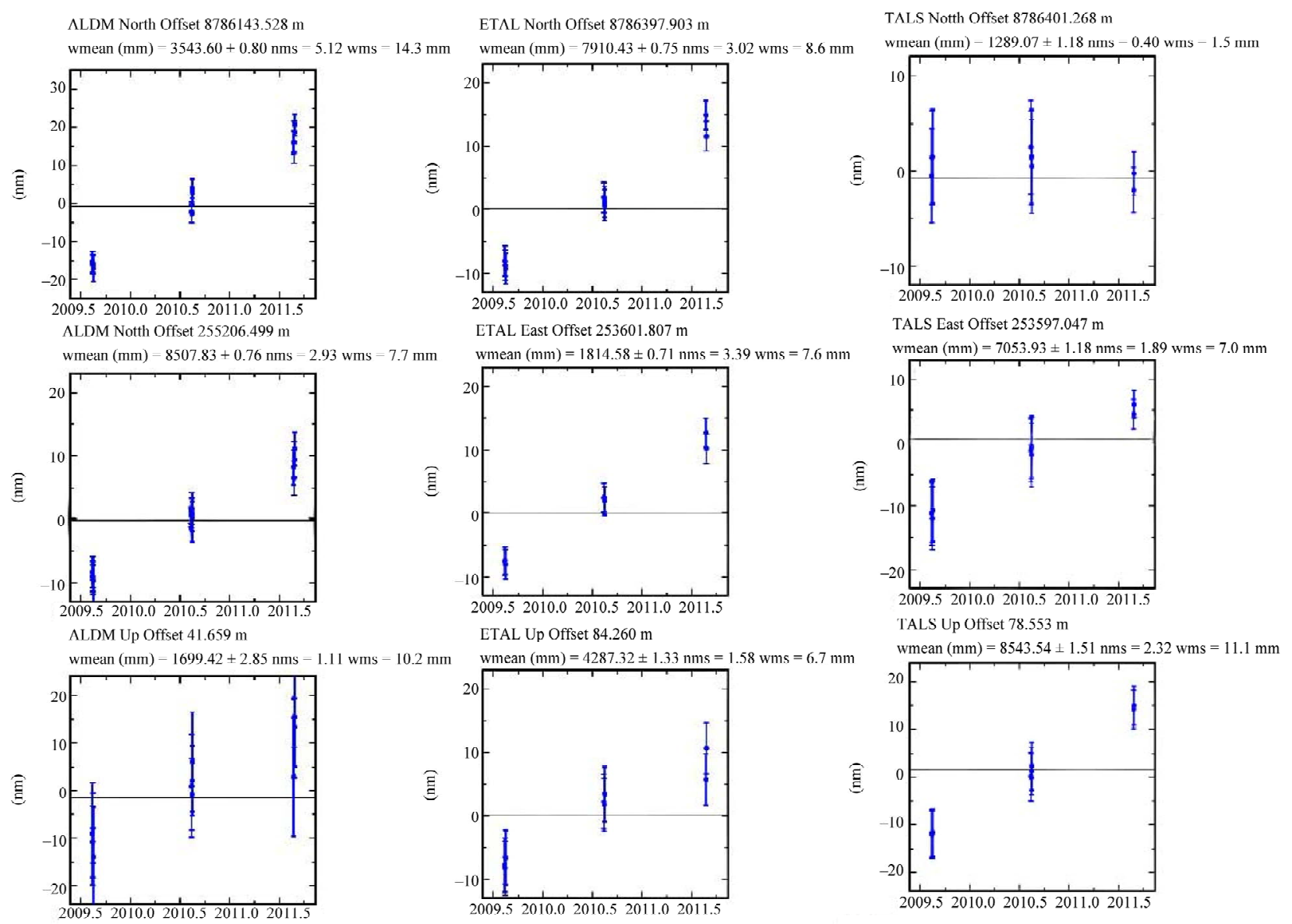

Figure 8. Time series plot of the campaign sites.

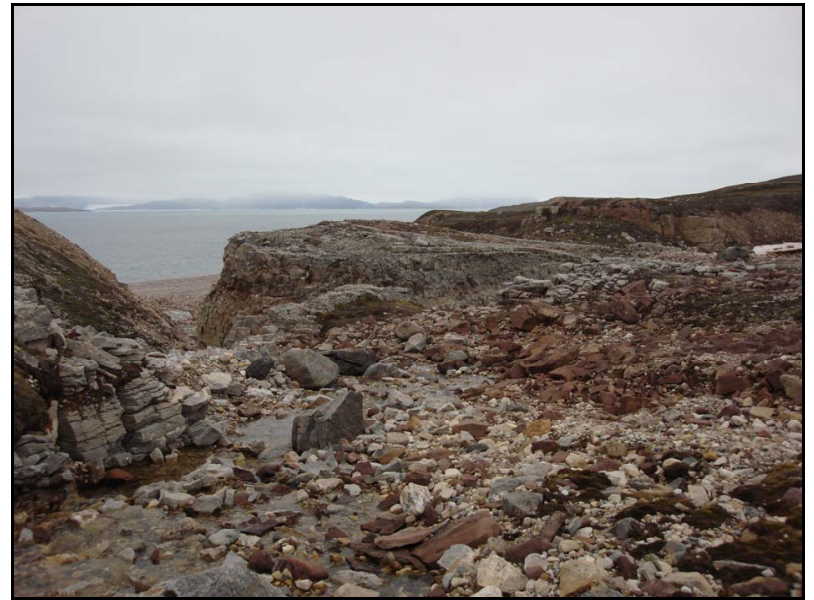

Figure 9. High erosion rates at Ny Alesund.

change, which is responsible for the isostatic rebound due to the snow melting phenomenon.

\section{Conclusion and Future Work}

The results presented in this research are preliminary at best and do indeed need a fourth epoch so that the results can correctly reflect the conditions present at arctic region. There are local deformations along existing faults, which seems to be active. The short time span of the observations includes only three epochs of GPS campaign. The resultant vector is $14.84 \mathrm{~mm} \cdot \mathrm{yr}^{-1}$ with a azimuth $27.670^{\circ} \mathrm{N}$, a vertical displacement of $7.62 \pm 3.0 \mathrm{~mm} \cdot \mathrm{yr}^{-1}$, which seems to be a higher estimates for isostatic rebound only at Arctic region. The geodetic observation around Fenno-scandian Shield suggest the $0.5 \mathrm{~mm} \cdot \mathrm{yr}^{-1}$, which indicate a lower rates of rebound due to the less extent of snow cover and seasonal changes during the years of observations. Our results are within the estimated rates of vertical displacement 12.5 to $6 \mathrm{~mm} \cdot \mathrm{yr}^{-1}$ from west to east [7]. Both poles have ice sheets, which exert more stress in the isostatic rebound. We need to continue more observations of GPS campaigns to rectify the errors for precise results. Since, Svalbard archipelago consists of number of islands, a carefully designed follow-up micro-earthquake activity in the Svalbard region is necessary to correlate the deformation rates with tectonic and glacial quakes in order to derive the best estimates for isostatic rebound, which is due to the snow melting vis$a$-vis climate change. 


\section{Acknowledgements}

The work is carried out at Arctic Region with the financial assistance provided by National Centre for Antarctic \& Ocean Research, Ministry of Earth Sciences Government of India is gratefully acknowledged. Authors are thankful to Dr. Vineet Gahalaut, Scientist NGRI for providing his valuable suggestions for the preparation of the manuscript.

\section{REFERENCES}

[1] D. L. Anderson and R. O'Connell, "Viscosity of the Earth," Geophysical Journal. Royal Astronomical Society, Vol. 14, No. 1-4, 1967, pp. 287-295. doi:10.1111/j.1365-246X.1967.tb06245.x

[2] J. M. Johansson, J. L. Davis, H.-G. Scherneck, G. A. Milne, M. Vermeer, J. X. Mitrovica, R. A. Bennett, B. Jonsson, G. Elgered, P. Elósegui, H. Koivula, M. Poutanen, B. O. Rönnäng and I. I. Shapiro, "Continuous GPS Measurements of Postglacial Adjustment in Fennoscandia. 1. Geodetic Results," Journal of Geophysical Research, Vol. 107, 2002, pp. 2157-2184.

[3] G. F. Sella, S. Stein, T. H. Dixon, M. Craymer, T. S. James, S. Mazzotti and R. K. Dokka, "Observation of Glacial Isostatic Adjustment in 'STABLE' North America with GPS," Geophysical Research Letters, Vol. 34, No. 2, 2007, Article ID: L02306. doi:10.1029/2006GL027081

[4] W. R. Peltier, "Postglacial Variations in the Level of the Sea: Implications for Climate Dynamics and Solid-Earth Geophysics," Reviews of Geophysics, Vol. 36, No. 4, 1998, pp. 603-689. doi:10.1029/98RG02638

[5] J. X. Mitrovica and W. R. Peltier, "Present-Day Secular Variations in Zonal Harmonics of the Earth's Geopotential," Journal of Geophysical Research, Vol. 98, 1993, pp. 4509-4526

[6] P. Wu and P. Johnston, "Can Deglaciation Trigger Earthquakes in N. America?" Geophysical Research Letters, Vol. 27, No. 9, 2000, pp. 1323-1326.

[7] P. Wu and W. R. Peltier, "Pleistocene Deglaciation and the Earth's Rotation: A New Analysis," Geophysical Journal of the Royal Astronomical Society, Vol. 76, No. 3, 1984, pp. 753-792.

[8] V. Schlindwein, C. C. Muller and W. Jokat, "Microseismicity of the Ultraslow-Spreading Gakkel Ridge, Arctic Ocean: A Pilot Study," Geophysical Journal International, Vol. 169, 2007, pp. 100-112. doi:10.1111/j.1365-246X.2006.03308.x

[9] D. Worsley, "Evolution of an Arctic archipelago," The Geological History of Svalbard, Statoil, 1986, p. 121.

[10] S. Elvevold, "Geology of Svalbard," Norweign Polar Institute, Tromsø, 2007, p. 35.

[11] A. Hjelle, "The Geology of Svalbard," Norsk Polarinstitutt, Oslo, 1993, p. 163.

[12] Blythe and Kleinspehn, "Tectonically versus Climatically Driven Cenozoic Exhumation of the Eurasian Plate Mar- gin, Svalbard: Fission Track Analyses," Tectonics, Vol. 17, No. 4, 1998, pp. 621-639.

[13] H. P. Plag, "Measurement of Vertical Crustal Motion in Europe by VLBI," Station Report for Ny-Alesund, Norwegian Mapping Authority.

[14] P. Tomasai and M. Rioja, "South-Western Europe Movement with VLBI," In H.-P. Plag, Ed., Book od Extended Abstracts for the 9th General Assembly of Working Group of European Geoscientists for the Establishment of Networks for Earth Science Research, 1998, pp. 64-65.

[15] B. J. Mitchell, H. Bungum, W. W. Chan and P. B. Mitchell, "Seismicity and Present Day Tectonics of the Svalbard Region," Geophysical Journal International, Vol. 102, No. 1, 1990, pp. 139-149.

[16] L. Bockmann, L. Grimstveit, B. G. Harsson, H. P. Kierulf, O. Kristiansen and H. P. Plag, "Site Surveys at the Fundamental Geodetic Station in Ny-Alesund," Norwegian Mapping Authority, Svalbard, 2007.

[17] O. Salvigsen, "Radiocarbon Dating and the Extension of the Weichselian Ice-Sheet in Svalbard," Norsk Polarinst Årbok, 1976, pp. 209-224.

[18] O. Salvigsen, A. Elgersma and J. Y. Landvik, "Radiocarbon Dated Raised Beaches in Northwestern Wedel Jarlsberg Land, Spitsbergen, Svalbard," Wyprawy Geograficzne na Spitsbergen, UMCS, Lublin, 1991, pp. 9-16.

[19] R. L. Hooke and A. Elverhøi, "Sediment Flux from a Fjord during Glacial Periods, Isfjorden, Spitsbergen," Global and Planetary Change, Vol. 12, 1996, pp. 237 249. doi:10.1016/0921-8181(95)00022-4

[20] A. Fiedler and J. I. Faleide, "Cenozoic Sedimentation along the Southwestern Barents Sea Margin in Relation to Uplift and Erosion of the Shelf," Global and Planetary Change, Vol. 12, 1996, pp. 75-93. doi:10.1016/0921-8181(95)00013-5

[21] W. K. Dallmann, Ed., "Lithostratigraphic Lexicon of Svalbard. Upper Palaeozoic to Quaternary Bedrock," Review and Recommendations for Nomenclature Use, Committee on the Stratigraphy of Svalbard/Norsk Polarinstitutt, 1999, p. 320.

[22] R. W. King and Y. Bock, "Documentation for GAMIT Analysis Software Release 10.4," Massachusetts Institute of Technology, Cambridge, 2010.

[23] T. A. Herring, "GLOBK: Global Kalman Filter VLBI and GPS Analysis Program," Department of Earth, Atmospheric and Planetary Sciences Massachusetts Institute of Technology, and Scripps Institution of Oceanography, University of California, San Diego, 2003.

[24] Z. Altamimi, X. Collilieux, J. Legrand, B. Garayt and C. Boucher, "ITRF2005: A New Release of the International Terrestrial Reference Frame Based on Time Series of Station Positions and Earth Orientation Parameters," Journal of Geophysical Research, Vol. 112, 2007, Article ID: B09401. doi:10.1029/2007JB004949

[25] T. Okuno, J. Hinderer, J. Daniel, S. M. Plag, H. P. Francis, O. Falk and R. Fukuda, "A Geophysical Interpretation of the Secular Displacement and Gravity Rates Observed at Ny-Ålesund, Svalbard in the Arctic-Effects of PostGlacial Rebound and Present-Day Ice Melting," Geo- 
physical Journal International, Vol. 165, No. 11, 2006, pp. 729-743.

[26] A. Hjelle, "Geology of Svalbard," Polar Handbook, No. 7, Norwegian Polar Institute, 1993, p. 162.

[27] O. Salvigen, A. Elgersma and J. Y. Landvik, "Radiocarbon Dating Raised Beach in Northwestern Wedel Jarlsberg Land, Spitsbergn Svalbard," Wypr. Geogr. Na Spitsbergen, UMCS, Lubin, 1991, pp. 9-16.

[28] R. L. Hooke and A. Lverhoi, "Sediment Flux from a Fjord during Glacial Period, Isfjorden, Spitsbergen," Global and Planetary Change, Vol. 12, 1996, pp. 237240. doi:10.1016/0921-8181(95)00022-4

[29] A. Fiedler and J. L. Faleeide, "Cenozoic Sedimentation along the Southwestern Barent Sea Margin in Relation to Uplift and Erosion to the Shelf," Global and Planetary Change, Vol. 12, No. 1-4, 1996, pp. 75-93.

[30] R. Dietrich, A. Rulke and M. Scheinert, "Present Day Vertical Crustal Deformation in West Greenland from Repeated GPS Observation," Geophysical Journal International, Vol. 163, No. 3, 2005, pp. 865-874.

[31] E. Gueguen, P. Tomasi, H.-G. Scherneck, R. Haas and J. Campbell, "Recent Crustal Movements: Geological Meaning of European Geodetic VLBnetwork Observations," Proceedings of 15th Working Meeting on European VLBI for Geodesy and Astrometry, Barcelona, 7-8 September 2002. 